\title{
Crop-climate ensemble scenarios to improve risk assessment and resilience in the semi-arid regions of West Africa
}

\author{
Seyni Salack ${ }^{1, *}$, Benoit Sarr ${ }^{2}$, Sheick K. Sangare ${ }^{2}$, Mouhamed Ly ${ }^{2}$, \\ Ibrah Seidou Sanda ${ }^{2}$, Harald Kunstmann ${ }^{1}$ \\ ${ }^{1}$ Institute of Meteorology and Climate Research-Atmospheric Environmental Research (IMK-IFU), \\ Karlsruhe Institute of Technology (KIT), Kreuzeckbahnstrasse 19, 82467 Garmisch-Partenkirchen, Germany \\ ${ }^{2}$ Département Formation et Recherche (DFR), Centre Régional AGRHYMET (CRA), BP 11011, 425 Boulevard de l'Université, \\ Niamey, Niger
}

\begin{abstract}
Estimation of the response of rainfed crops to heat stress and water stress must adequately account for the uncertainty in climatic and non-climatic factors that affect impact assessments. The objective of this research was to narrow the range of values characterizing the limits within which estimates are expected to fall in the diagnostics of agroclimatic risks. Assessments were made by analyzing historical observations and evaluating the influence of heat stress and rainfall variability on crop water demand, biomass and grain yields of short-cycle cultivars of pearl millet and maize. We used a wide range of consistent and practical sets of crop model ensemble analyses (based on crop management practices such as plant density, fertilization levels, early/late sowing dates and soil types) and climate model ensembles from 2 climate change hypothesis (A1b and RCP8.5) over the West African Sudan-Sahel. Recent rainfall developments show that hazardous intra-seasonal rainfall distribution affects crop productivity, with increased frequency and intensity of daily rainfall, false start and early cessation of the rainy season and decreasing diurnal temperature range. In 2011-2050 perspectives, relative to the 1981-2010 baseline, a slight increase in temperature (i.e. +0.6 to $+0.8^{\circ} \mathrm{C}$ ) combined with a stationary to moderate decrease in precipitation leads to a 10 to $15 \%$ (8 to $15 \%$ ) decrease in aboveground biomass production (grain yield). When the warming is moderate (i.e. +1.4 to $1.8^{\circ} \mathrm{C}$ ), the decline in grain yield worsens (10 to $20 \%$ ), despite a slight increase in rainfall projections. At these rates of loss in crop production, resilience can be reinforced. However, it will require that climate-smart crop management practices be embedded in sub-seasonal and interannual monitoring and early warning systems.
\end{abstract}

KEY WORDS: Agroclimatic risks - Ensemble scenarios · Uncertainty management · Sensitivity analysis $\cdot$ Pearl millet $\cdot$ Maize $\cdot$ West African Sudan-Sahel

\section{INTRODUCTION}

According to the assessment reports of the IPCC (IPCC 2007, Porter et al. 2014), global warming will be faster than expected and will remain inexorable with or without mitigation measures during the first half of the 21st century. Therefore, rising temperature trends are the common features found in the analysis of climate projections provided by both regional and global climate models. However, several sets factors affect the range of values characterizing the limits within which impact estimates are expected to fall. In agroclimatic risk assessment, these factors are sources of uncertainty. Over the West African Sudan-Sahel (WASS), there is a clear divergence among models on both the magnitude and sign of precipitation 
trends (Paeth et al. 2011). Part of this uncertainty may be related to the significant different model responses to greenhouse gas forcing (Cook 2008). Robust projections of agricultural production require adequate management of this discrepancy among climate models. A first alternative is to use more than one climate model (Alexandrov \& Hoogenboom 2000, Porter et al. 2014) and make more adequate use of ensemble simulations to reduce the effect of the uncertainty due to model discrepancy on the estimation of crop response to climate variability and change (Oettli et al. 2011, Challinor et al. 2013). Other sources of uncertainty such as (1) the wellknown mismatch between the scale at which climate processes are resolved in climate models (mostly tens to hundreds of kilometers) and the plot scale at which most crop models resolve plant phenological processes (tens of meters) (Baron et al. 2005) and (2) the bias transfer between global/regional climate models and crop models (Oettli et al. 2011, Salack et al. 2012, Lobell 2013). To better manage these sources of uncertainty, climate model outputs statistics and the development of synthetic scenarios are breakthrough solutions.

The estimation of cropping systems' response to climate variability and change depends also on our ability to better understand the relationship among model complexity, measured uncertainty and actual uncertainty and the manner in which this varies across spatial scales (Challinor et al. 2013). A way to achieve this understanding is to assess model parametric sensitivity with respect to on-farm sources of uncertainty. One of the sources of uncertainty is the lack of well-established crop-soil management practices in millet and maize farming systems in the WASS. Several field surveys show that actual sowing date, plant density and fertilization (timing and amount) are unevenly practised among farmers, and highly influenced by tradition rather than scientific recommendation. For example, over a $100 \times 120 \mathrm{~km}$ square region in Niger, Balme et al. (2005) found an $11 \mathrm{~d}$ standard deviation for the average planting dates across 30 rain gauges. This result was based on rainfall threshold analysis of planting dates and does not include dry seeding, which is a planting option carried out very often by farmers in this region. An analysis of observed millet yield across 10 villages in a $100 \times 100 \mathrm{~km}$ square also revealed a $2000 \mathrm{~kg} \mathrm{ha}^{-1}$ difference across farms in the same village and a $1000 \mathrm{~kg} \mathrm{ha}^{-1}$ difference between villages. This variability cannot be explained by spatial rainfall variability, soil fertility or seedling density (Sultan et al. 2008).
The objectives of this paper are to (1) detect agroclimatic risks related to historical trends in temperature and rainfall and (2) estimate the singular and combined near-future effects of changes in temperature and rainfall regimes on crop water demand, biomass and grain yields of short-cycle cultivars of pearl millet and maize. The study is further linked to best practices in early warning systems for resilience in the region. To manage sources of uncertainty in the assessments, we gathered high-quality local climate data and crop/soil management information, and developed a series of consistent and practical crop model sensitivity analyses (based on crop management practices such as seedling densities, fertilization levels, early/late sowing dates and soil types) and climate impact assessment scenarios based on outputs from climate models (A1b and RCP8.5 scenarios).

\section{DATA AND METHODS}

\subsection{Indices for historical diagnostics}

Observed climate data including daily rainfall and maximum and minimum temperature were contributed by the meteorological services and agencies of the member states of the Permanent Interstates Committee for Drought Control in the Sahel/Economic Community of West African States (CILSS/ ECOWAS) through AGRHYMET's regional database. A total of 119 rainfall recording stations have qualitycontrolled daily time series from 1950 to 2010. Among these 119 stations, 64 well-distributed synoptic stations also provide daily minimum and maximum temperatures from 1960 to 2010 (Fig. 1). They fall within the region where annual rainfall is between $200 \mathrm{~mm}$ and a little less than $1200 \mathrm{~mm}$, according to observations illustrated in Fig. 1. Annual rainfall and temperature anomalies were computed relative to the 1961-1990 period. All historical data sets of rainfall and temperatures were used to compute agroclimatic indices such as onset/cessation dates, false onset/ early cessation dates (as defined by Salack et al. 2014), frequency of intense rainy days and diurnal temperature range. Onset/cessation dates were computed following the classical method defined in Alhassane et al. (2013). The onset date is the day after May 1 when $20 \mathrm{~mm}$ totalled over 1 to $3 \mathrm{~d}$ is not followed by a dry spell $\geq 20$ days in the next 30 days. The cessation date is the day after September 1 when soil water content is $\leq 0.05 \mathrm{~mm}$. A false onset of the rainy season is defined as between May 1 and July 31, with 


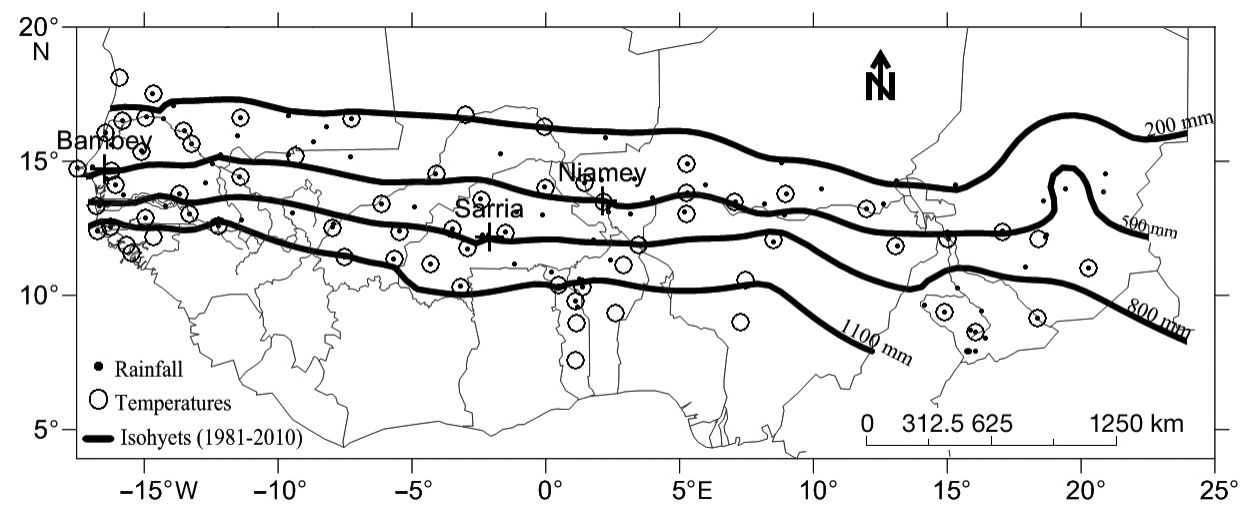

Fig. 1. Spatial distribution of reference stations and $30 \mathrm{yr}$ average rainfall climatology of the Sudan-Sahel region. The dots are the rainfall stations. The open circles are the stations where daily maximum and minimum temperatures are available. Only the stations with both rainfall and temperatures are used as reference stations for the impact assessment on millet and maize. Bambey (Senegal), Sarria (Burkina-Faso) and Niamey (Niger) experimental/survey site data sets are used in the crop model evaluation process. The contours are mean annual rainfall computed over the 1981-2010 period

a rainy day preceding the start of a dry spell longer than $14 \mathrm{~d}$, and early cessation is the first day of a dry spell event $>8 \mathrm{~d}$ but $<15 \mathrm{~d}$. Details on the definitions and computational schemes of false onset and early cessation dates can be found in Salack (2013) and Salack et al. (2014). These indices were used in a threshold analysis to determine their potential risks to rainfed short-cycle cereals in the study area. The 64 synoptic stations are the reference stations for the impact assessment simulations.

\subsection{Minimum data sets for baseline simulations}

The Decision Support System for Agrotechnology Transfer (DSSAT) is a process-based model capable of simulating the growth, development and yield of around 20 food, fodder and cash crops. Other modules include water balance, nitrogen, phosphorus and soil carbon models. All modules are interlinked in an interface called the DSSAT cropping system model (DSSAT-CSM) (Jones et al. 2003, Hoogenboom et al. 2010). The DSSAT-CSM (version 4.5) is a user-friendly interface that also allows for easy calibration and validation (based on experimental data) and assessment of climate change impact on crop production and cropping systems using user-defined scenarios (Alexandrov \& Hoogenboom 2000, Hoogenboom et al. 2010). In a complete simulation setting, DSSATv4.5 accounts for soil physical, chemical and hydrological properties at different depths; climate (minimum and maximum temperature, rainfall and solar radiation, wind speed); crop biophysical characteristics (genetic and ecophysiological parameters); and crop management techniques (fertilization, sow- ing date, seedling density, rainfed/irrigated) (Hoogenboom et al. 2012). It is a valuable decision support tool under adverse soil and climatic conditions such as those found in the WASS and is currently among the most widely used crop models in climate impact assessment studies in Africa (Bationo et al. 2012).

To fulfill the minimum data requirements as recommended by Hoogenboom et al. (2012), the 64 reference stations and a regular $50 \times 50 \mathrm{~km}$ grid were overlaid on the Food and Agriculture Organization of the United Nations (FAO) soil type map (FAO/ UNESCO 2003). The dominant soil type in a pixel was used to represent the soil type for each of the 64 reference stations that falls within the pixel. The edaphic parameters from the surface to $2 \mathrm{~m}$ depth (i.e. percent clay, silt, stones, organic carbon, total nitrogen, $\mathrm{pH}$ in water) of each dominant soil type were extracted from literature (Djaby et al. 2001, Annou 2003, Keita 2003, Khouma 2003, Kissou et al. 2003). When a soil profile was not found we used (1) the World Inventory of Soil Emission Potentials (WISE) database (Gijsman et al. 2007) or (2) the bestfitting metasoil types, taking into account soil organic carbon content (high/medium/low), soil rooting depth as a proxy for available water content (deep/medium/ shallow) and major constituent (sand/loam/clay). These soil data sets are available in the released version of DSSATv4.5.

For the impact assessment simulations and analysis, we chose the most recent $30 \mathrm{yr}$ time series, 1981-2010, as the baseline following the recommendations by White et al. (2011). To complete the minimum data set required for simulations in DSSAT-CSM, we completed the missing daily solar radiation, wind speed and relative humidity from 
NASA's Prediction of Worldwide Energy Resource (POWER) data (http://power.larc.nasa.gov/). The parameters contained in the agroclimatology archive of this portal are based primarily on solar radiation derived from satellite observations and meteorological data from assimilation models. These climate data were checked for conformity before use in gap filling of the 1981-2010 baseline (Figs. 1 \& S2 in the Supplement at www.int-res. com/articles/suppl/c065p107_supp.pdf. The baseline data set was used to simulate the production of 3 millet cultivars (Souna 3, Zatib and HKP, Alhassane et al. 2006, Salack 2013) and 2 maize cultivars (OBATAMPA, EV-8443). The performance of the crop model was evaluated prior to impact assessments (Tables S1 \& S2, Fig S3 in the Supplement). Another climate data set included near-future synthetic scenarios, which are described below in Section 2.3 .

\subsection{Crop management scenarios for sensitivity analysis}

In the WASS, chemical fertilizer use is usually low. More often than not, the fertilization level is inadequate and very different between farmers. To estimate the subsequent response of some sets of subsistence cereals and the range of non-climatic drivers (e.g. crop management practices) that affect smallholder farming, we developed the following scenarios, which were used in an ensemble of sensitivity runs of DSSAT:

1. Non-photoperiodic cultivars - millet (Souna 3, $90 \mathrm{~d}$; Zatib, $100 \mathrm{~d}$ i HKP, $90 \mathrm{~d}$ ); maize (OBATAMPA, 90 di EV-8443, 70 d);

2. Rainfed cropping system - dry seeds are planted at 5 to $7 \mathrm{~cm}$ depth in a $100 \times 100 \mathrm{~cm}$ row spacing; only 2 to 3 plants $\mathrm{m}^{-2}$ are observed at emergence;

3. Sowing date - the first day between April 1 and July 31 when at least $40 \%$ soil moisture in the top $20 \mathrm{~cm}$ depth is reached, minimum temperature does not drop below $11^{\circ} \mathrm{C}$ for millet cultivars (below $8^{\circ} \mathrm{C}$ for maize) and maximum temperature does not exceed $35^{\circ} \mathrm{C}$;

4. Use of fertilizer -4 treatments are considered: run0, $0 \mathrm{~kg}$ of nitrogen; run1: $100 \mathrm{~kg} \mathrm{ha}^{-1}$ of nitrogen, phosphorus and potassium (NPK) at sowing; run2: $100 \mathrm{~kg}$ of NPK at sowing $+50 \mathrm{~kg}$ of urea $40 \mathrm{~d}$ after sowing; run3: $100 \mathrm{~kg}$ of NPK at sowing $+50 \mathrm{~kg}$ of urea at $20 \mathrm{~d}$ after sowing $+50 \mathrm{~kg}$ of urea at $40 \mathrm{~d}$ after sowing; organic matter is added in the form of $500 \mathrm{~kg}$ $\mathrm{ha}^{-1}$ of crop residues to all treatments.

\subsection{Climate change scenarios for impact assessments}

The generation of robust projections of agricultural production must adequately account for the uncertainty in future atmospheric composition and climate (Challinor et al. 2013). To manage these sources of uncertainty, we post-processed a set of outputs of 4 regional climate models (RCMs) driven by 2 global climate models (GCMs) using the A1b emission scenario from the IPCC Fourth Assessment Report, as well as 3 coupled atmosphere-ocean global climate models (AOGCMs) and 3 earth system climate models (ESMs) forced with representative concentration pathway 8.5 (RCP8.5) from the IPCC Fifth Assessment Report (for climate model names and category, see Table 1).

The analysis of these model outputs gives a regional warming interval of +0.6 to $+1.8^{\circ} \mathrm{C}$, corresponding to the 25th percentile of the ensembles, for the period 2011-2050 (Fig. 2a). This warming interval from all categories of climate models, referred to as the 'regional warming range', is associated with rainfall variability under 2 perspectives: (1) A moderate warming is associated with a normal rainfall regime (stationary rainfall pattern) in 20112050 (SN0). The SN0 scenario is referred to as the neutral scenario. It has 2 members, detailed in Table 2. (2) A moderate warming is associated with a variable rainfall regime in 2011-2050 (SNP). The SNP is referred to as the scenario of rainfall variability. The members of this scenario are listed in Table 2. In scenario member SN10-30, we considered a $10 \%$ decrease in precipitation from 2011 to 2030, while in scenario member SP07-50, we considered a $7 \%$ increase from 2031 to 2050. These rates of change are plausible when we consider the ensemble average of the climate models over the WASS sub-region (Fig. 2b).

Using the families of scenarios in Table 2, we generated climate data by perturbing the daily time series of the baseline period 1981-2010 of each reference station. These synthetic climate data were used to study the effect of changes in precipitation both separately and in combination with changes in temperature. This approach has already been suggested by Salack et al. (2012) to identify the effect of intraseasonal distribution of rainfall parameters and by Waha et al. (2013) to estimate the separate and combined effects of water and heat stresses on crop. It stands as an alternative method of managing uncertainty related to post-processing or statistical downscaling of climate model outputs (Salack 2013). 
Table 1. List of climate models used for the analysis

\begin{tabular}{|c|c|c|c|c|c|}
\hline Modelling group & Institute ID & Model name & Model type & Scenario & $\begin{array}{l}\text { Horizontal } \\
\text { resolution }\end{array}$ \\
\hline $\begin{array}{l}\text { Beijing Climate Center, China } \\
\text { Meteorological Administration }\end{array}$ & BCC-CMA & BCC-CSM1.1 & Coupled climate system model & RCP8.5 & $2.8^{\circ} \times 2.8^{\circ}$ \\
\hline $\begin{array}{l}\text { Australian Commonwealth Scientific } \\
\text { and Industrial Research Organization }\end{array}$ & $\begin{array}{l}\text { CSIRO } \\
\text { RCP8.5 }\end{array}$ & $\begin{array}{l}\text { CSIRO-Mk3-6-0 } \\
1.9^{\circ} \times 1.9^{\circ}\end{array}$ & $\begin{array}{l}\text { Coupled atmosphere-ocean } \\
\text { global climate model (AOGCM) }\end{array}$ & & \\
\hline Institut Pierre-Simon Laplace, France & IPSL & IPSL-CM5A-LR & $\begin{array}{l}\text { Earth system model (ESM)- low } \\
\text { resolution }\end{array}$ & RCP8.5 & $3.75^{\circ} \times 1.87^{\circ}$ \\
\hline Institut Pierre-Simon Laplace, France & IPSL & IPSL-CM5A-MR & ESM-medium resolution & RCP8.5 & $2.5^{\circ} \times 1.25^{\circ}$ \\
\hline $\begin{array}{l}\text { Atmosphere and Ocean Research Institute, } \\
\text { National Institute for Environmental } \\
\text { Studies, Japan Agency for Marine-Earth } \\
\text { Science and Technology, Japan }\end{array}$ & $\begin{array}{l}\text { AORI, NIES, } \\
\text { JAMSTEC }\end{array}$ & MIROC5 & Coupled AOGCM & $\mathrm{RCP} 8.5$ & $0.5^{\circ} \times 1.4^{\circ}$ \\
\hline Norwegian Climate Centre, Norway & $\mathrm{NCC}$ & $\begin{array}{l}\text { NorESM1-M } \\
\text { CLM }\end{array}$ & $\begin{array}{l}\text { ESM-intermediate resolution } \\
\text { Regional climate model (RCM) } \\
\text { forced by ECHAM5_r3 }\end{array}$ & $\begin{array}{l}\mathrm{RCP} 8.5 \\
\mathrm{~A} 1 \mathrm{~b}\end{array}$ & $\begin{array}{c}2^{\circ} \times 2^{\circ} \\
0.44^{\circ} \times 0.44^{\circ}\end{array}$ \\
\hline $\begin{array}{l}\text { UK Met Office, Hadley Centre for Climate } \\
\text { Prediction and Research (HC) }\end{array}$ & $\mathrm{HC}$ & HadRM3P & RCM forced by HadCM3Q0 & A1b & $0.44^{\circ} \times 0.44^{\circ}$ \\
\hline $\begin{array}{l}\text { The Royal Netherlands Meteorological } \\
\text { Institute }\end{array}$ & KNMI & RACMO & RCM forced by ECHAM5_r3 & $\mathrm{A} 1 \mathrm{~b}$ & $0.44^{\circ} \times 0.44^{\circ}$ \\
\hline Max Planck Institute, Germany & MPI & REMO & RCM forced by ECHAM5_r3 & A1b & $0.44^{\circ} \times 0.44^{\circ}$ \\
\hline
\end{tabular}

\section{RESULTS}

\subsection{Historical trends in rainfall and temperature}

The rainfall regime in the WASS is unimodal, and the cropping season is confined between June and October. During the 1970s and 1980s, the area experienced a sharp decrease in rainfall (Lebel \& Ali 2009). A clear break of negative anomalies is observed in the rainfall pattern from 1968 until the early 1990s (Fig. 3a). In those years, the rainy season was characterized by late sowing and early cessation dates as well as by more frequent dry spells (Salack 2013). In those drought years, short-cycle, nonphotoperiodic cultivars such as Souna 3, HKP and Zatib were developed by local agricultural research centers and extended to the traditional farming system as solutions to the agroclimatic risks. Today, they are the most widely used pearl millet cultivars in rainfed subsistence farming in the WASS.
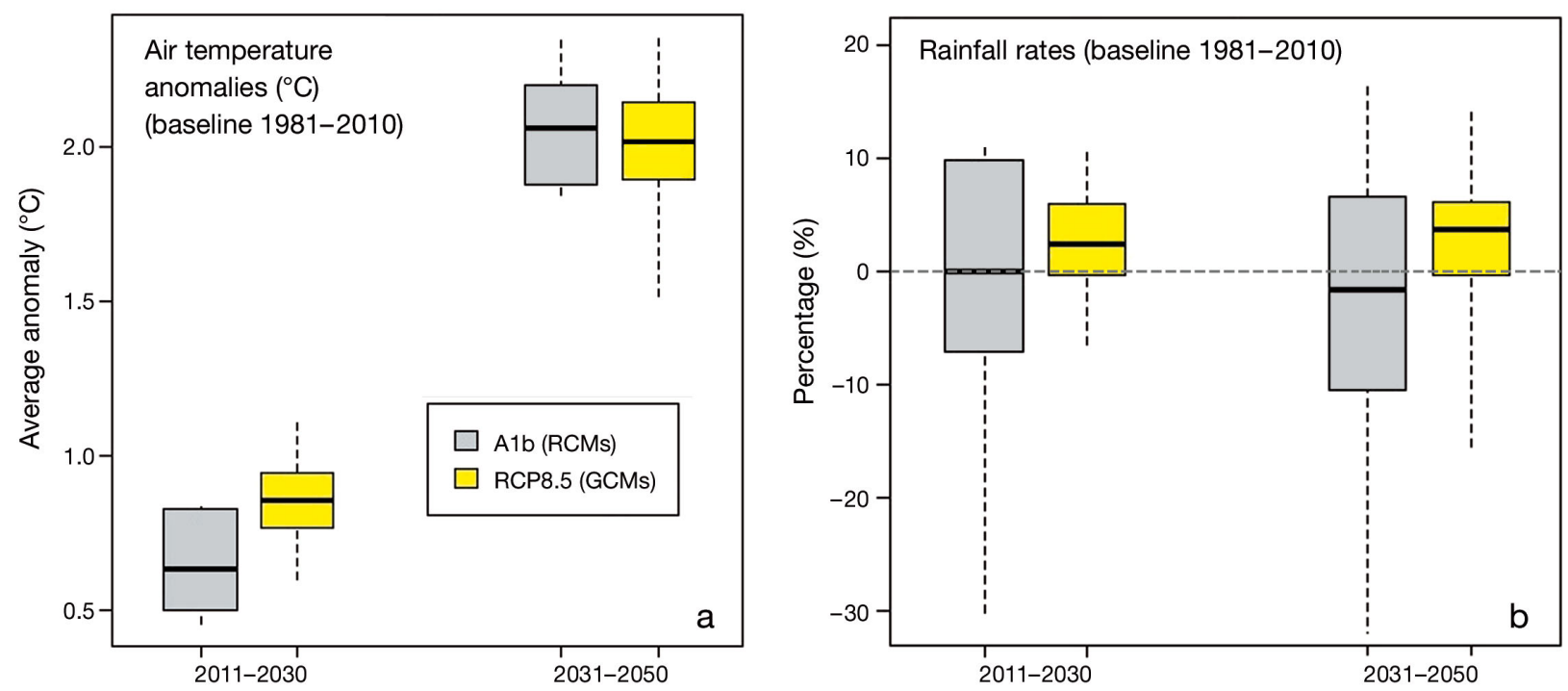

Fig. 2. Rates of (a) temperature and (b) rainfall increase over the West African Sahel according to an ensemble of climate models for the period 2011-2050 relative to the baseline 1981-2010. In RCP8.5, the baseline is 1981-2005 for all global climate models (GCMs)/earth system climate models/atmosphere-ocean general circulation models. Bottom and top of boxes: 25 th and 75 th percentiles, respectively; horizontal segment inside box: median; whiskers: minimum/maximum values distributed over the region 
Table 2. Families of scenarios that describe the prospects of future warming and rainfall variability over the period 2011-2050 in the West African Sudan-Sahel

\begin{tabular}{|lll|}
\hline Scenario family & Member & Definition (relative to baseline 1981-2010) \\
\hline Neutral scenario (SN0) & SN0-30 & $+0.6^{\circ} \mathrm{C}$ increase in temperatures with stationary rainfall $(+0 \%)$ in 2011-2030 \\
& SN0-50 & $+1.8^{\circ} \mathrm{C}$ increase in temperatures with stationary rainfall $(+0 \%)$ in 2031-2050 \\
Variability scenario (SNP) & SN10-30 & $+0.8^{\circ} \mathrm{C}$ increase in temperatures with 10\% decrease of rainfall in 2011-2030 \\
& SP07-50 & $+1.8^{\circ} \mathrm{C}$ increase in temperatures with 7\% increase of rainfall in 2031-2050 \\
\hline
\end{tabular}

Since the mid-1990s, there has been an apparent return to normal to above-normal rainfall conditions relative to the drought conditions of the 1970 s and 1980s. Despite this return to normal, the rainfall regime was still characterized by an increased variability of seasonal and intraseasonal rain events (Alhassane et al. 2013). In addition, there has been an increase in temperature over the region (Ly et al. 2013, Porter et al. 2014). The minimum (maximum) temperature increase in $1991-2010$ is $+0.88^{\circ} \mathrm{C}$ $\left(+0.68^{\circ} \mathrm{C}\right)$ with respect to the $1960-2010$ average (Fig. 3b). Temperatures in West Africa, particularly in the Sudan-Sahel, have evolved somewhat faster than the global average since the late 1980s. The increase becomes continuous and more marked for the minimum than the maximum temperature (Fig. 3b). These conditions are often associated with intense rainfall and more frequent flooding, causing extensive damage to crop production (Sarr 2011). The increased variability of rainfall associated with a relatively warmer climate tends to make agricultural planning and management challenging, with the consequent prevalence of food security stress in the region.

\subsection{Agroclimatic risks related to observed rainfall and temperature trends}

\subsubsection{Irregular cropping calendar}

Historical station data analysis has shown that the period 1950-1969 (P1), in which above-normal rainfall was observed, recorded early onset and late cessation dates of the rainy season (Le Barbé et al. 2002). An analysis of the time lag between the false onset (early cessation) dates of the cropping season relative to the regional transition period of the monsoon onset over the Sahel region is illustrated in Fig. 4. June 10 is the 3rd quartile monsoon onset date of the humid period (P1) and September 30 is the 3 rd quartile cessation date of the dry pe-
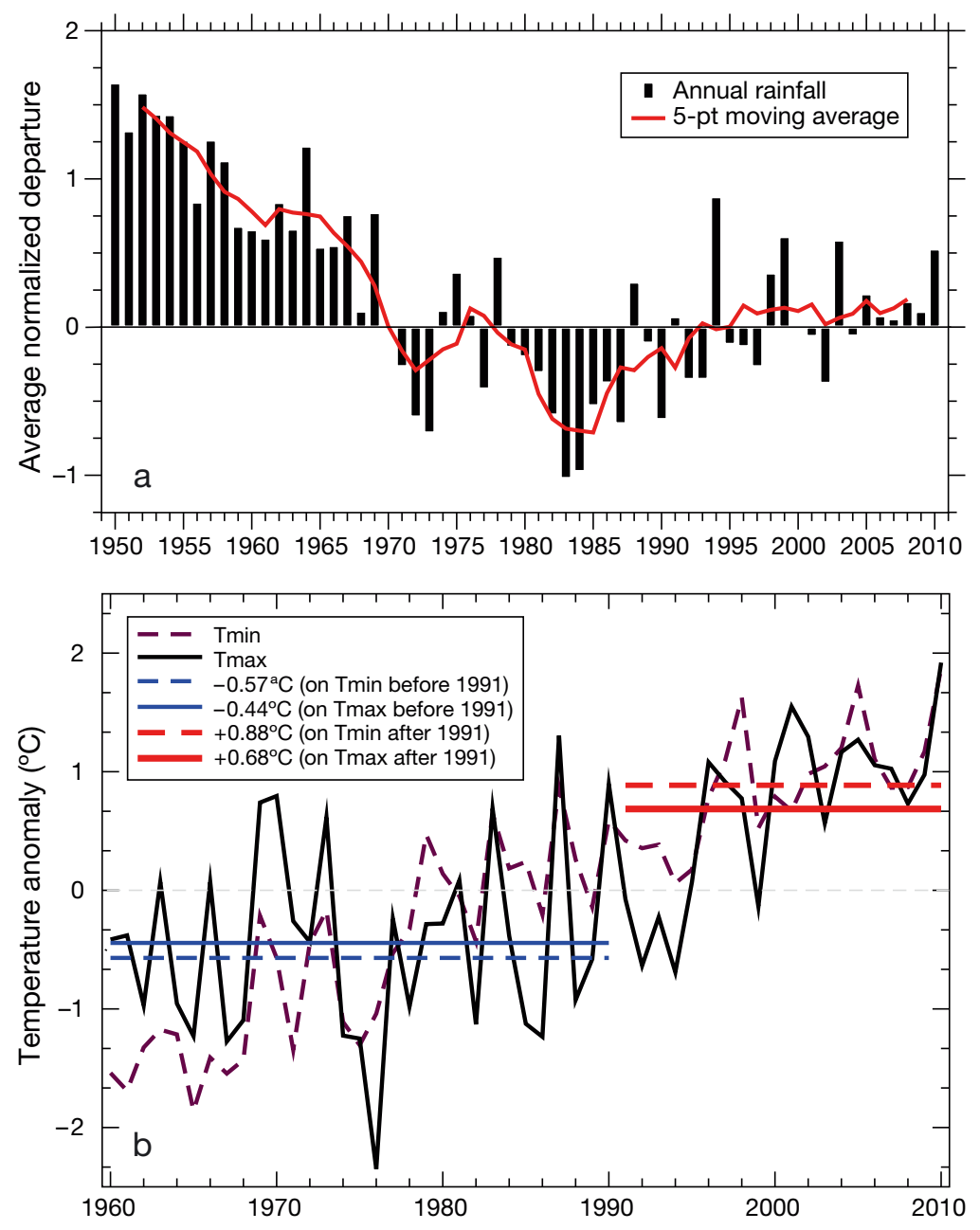

Fig. 3. Interannual variability of observed rainfall and temperatures areaaveraged over the West African Sudan-Sahel. (a) Regional rainfall anomalies normalized relative to 1961-1990 baseline. The red curve is a 5 yr centered moving average. (b) Temperature anomalies (not normalized) relative to 1960-2010. Blue (red): mean anomaly before (after) 1991. Dashed (solid) lines: minimum temperature (maximum temperature) 
Fig. 4. Median time lag between monsoon onset (cessation) dates and false start (early cessation) dates of the cropping season over the West African Sahel-Sudan (historical data analysis of 119 daily rainfall stations). Vertical full line: time lag 0 corresponding to June 10 (September 30) date (Alhassane et al. 2013). Vertical dashed lines: median values of P1, P2 and P3.The onset median value for $\mathrm{P} 1$ is $16 \mathrm{~d}$ earlier and that of $\mathrm{P} 3$ is only $5 \mathrm{~d}$ earlier compared to $\mathrm{P} 2$

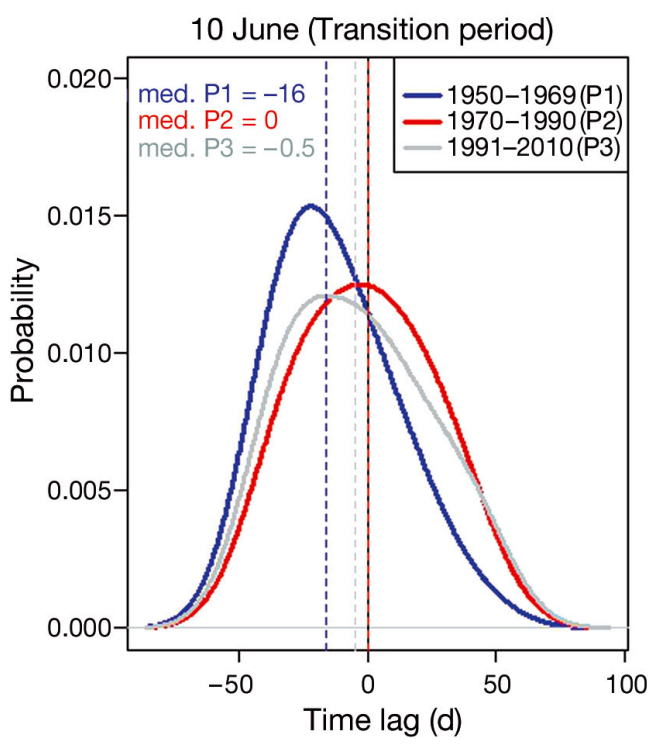

riod (P2) as defined by Alhassane et al. (2013). During the humid years of P1, false onset events were more common 2 wk before June 10 (with 16 d median time lag). During the period 1970-1990 (P2), in which rainfall totals were below normal (drought period) and rainy seasons were shorter (Alhassane et al. 2013), false onset was very likely in mid- to late June. In the recent 2 decades, 1991-2010, which were characterized by average rainfall close to normal conditions, the risk of false start/early end of the season was also very likely (Fig. 3). The similarity between the drought period and recent years reveals the persistence of the same agroclimatic risks such as seed abortion, low transplantation potential and shortening of crop growing season as a result of a highly irregular farming calendar. There is also a potential increase in water stress promoted by the increased length of dry spells during the reproductive phase of field crops (Alhassane et al. 2013, Salack 2013). Other observed agroclimatic risks include the fact that newly emerging plants are buried by sand storms and density currents that precede the irregular mesoscale convective systems associated with intermittent rainfall events in May to July.

\subsubsection{Increased frequency of intense rainfall events}

The frequency of intense daily rainfall has increased significantly in the 1991-2010 period (Fig. 5). The figure shows a significant increase in the number of intense rainy days in the last 2 decades. This becomes visible only when the numbers of heavy and very heavy rainy days are extracted from the total annual number of rainy days, as shown in Fig. 5c,d. This increasing trend is very similar to that of the humid period of 1950-1969 and is often associated with intense rainfall and more frequent flooding, causing extensive damage to crop production (Sarr 2011). The consequences on crop production include farm flooding, water logging of lowland crops, arable soil erosion through excess runoff and possibly pollen washing.

It is established that the tropical oceans exert a dominant influence on the climate of the Sahel. SST anomalies explained the persistence of drought in the 1970s and 1980s (Giannini et al. 2003, Neelin et al. 2003). Recent results also show a significant correlation between SST warming of the Indian-PacificNorth Atlantic oceans and the frequency and intensity of rainfall events (Giannini et al. 2013) and extreme dry spell occurrence at the onset and end of rainy seasons (Salack et al. 2014) in the WASS. If this relationship prevails, as shown by climate change projections, and the tropical oceans continue to warm, then the WASS may experience a highly variable rainfall distribution in the near future (Giannini et al. 2013). An increased variability implies that the agronomic quality of the rainy season is in jeopardy. Locally, this translates into a growing uncertainty on rainfed agricultural production.

\subsubsection{Decreased diurnal temperature range}

Temperature is an important environmental factor for crop growth and production. The growth rate from one phenological stage to another depends on the temperature values the crop is exposed to during 

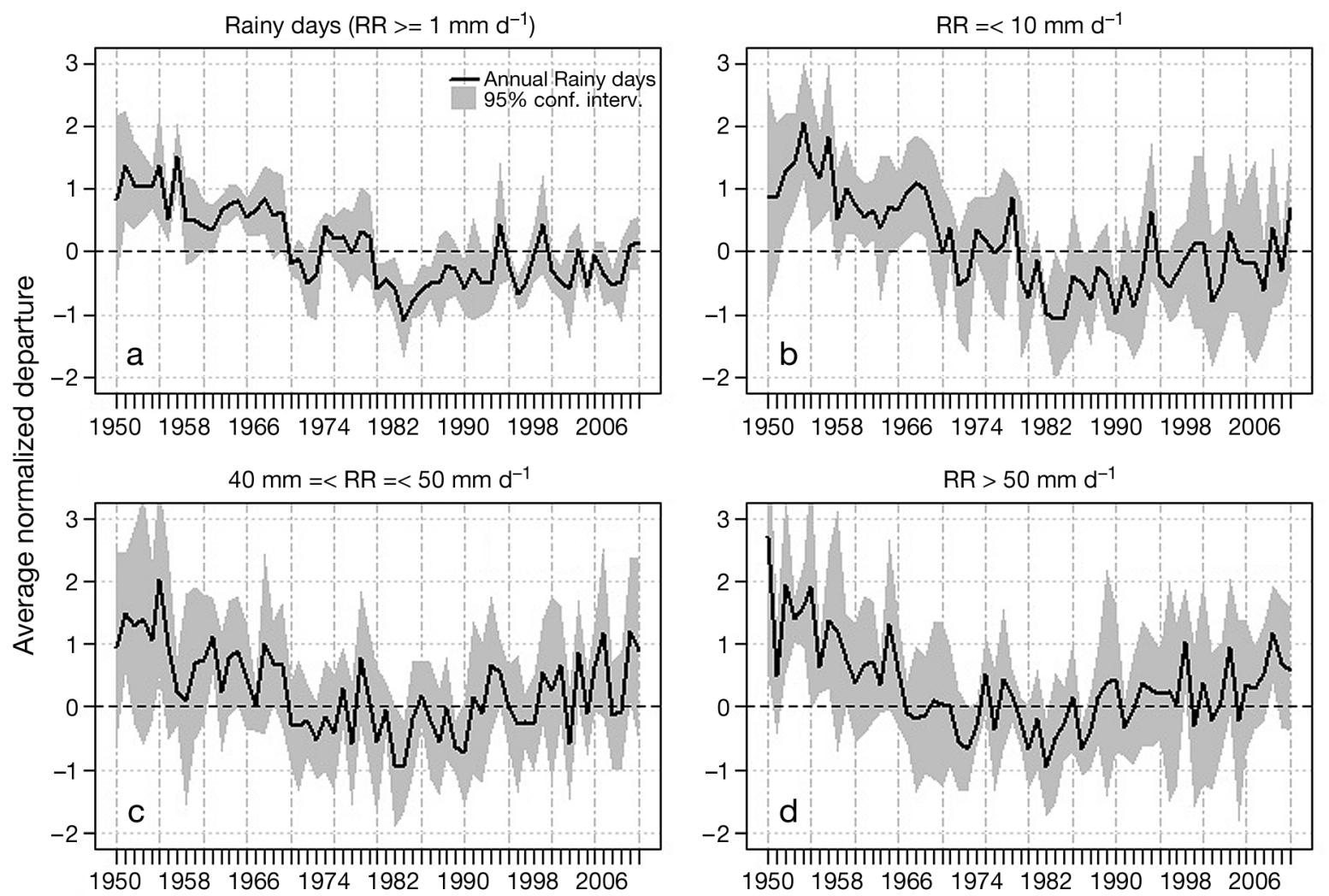

Fig. 5. Interannual variability of the number of rainy days (RR). (a) All rainy days, (b) light rainy days, (c) heavy rainy days, and (d) very intense rainy days

the vegetative cycle. The total amount of heat absorbed by the crop during its life cycle is a metric referred to as the growing degree-day (GDD). The GDD varies from one cultivar to another and describes the relationship between crop growth stages and air temperature amplitudes. However, it is relatively constant for each phase of the crop. Both maximum and minimum temperatures have increased over the WASS region, with faster warming in minimum temperature (Ly et al. 2013). The more pronounced increase in minimum temperature explains the decreasing trend in the diurnal temperature range (Fig. 6). Therefore, a decrease in the diurnal temperature range leads to a rapid accumulation of GDD of short-cycle, non-photosensitive cultivars and a reduction in length of some development phases and of the overall growth cycle. The increase in minimum temperature also means that nighttime temperatures are increasing. According to some experimental records, high nighttime temperature decreases crop production by decreasing photosynthetic function and sugar and starch content, increasing respiration rate, suppressing floral development and hastening crop maturity (Jones 1992, Abrol \& Ingram 1996).

\subsection{Impacts of heat stress and rainfall variability}

\subsubsection{Effects on growth cycle and water requirements}

The results from scenario SN10-30 (SP07-50) indicate a shortening of the growth cycle duration of all cultivars by $4 \mathrm{~d}(8 \mathrm{~d})$ over the region, with an estimated standard deviation of $2 \mathrm{~d}$. The decrease corre-

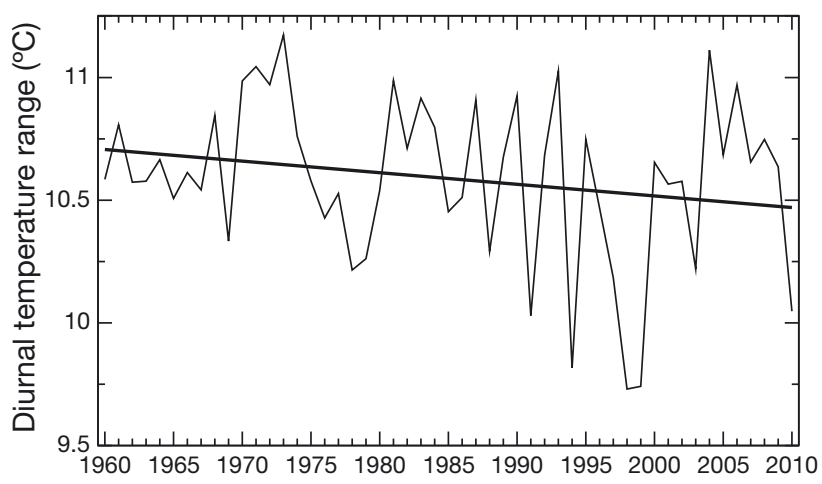

Fig. 6. Interannual variability of diurnal temperature amplitude averaged over the June to October sub-seasonal period over the West African Sahel region (historical data analysis of 64 daily temperature/rainfall stations) 
sponds to $5 \%(12 \%)$ of the normal growth cycle of these cultivars (Fig. 7, upper panels). These results are identical to those found in the analysis of neutral scenario (SN0) members, which consist of warming associated with a stationary rainfall regime. This reduction is mainly due to the increase in temperature, which accelerates the development of these crops. Each cultivar is characterized by temperature requirements during its various growth stages. The growth rate per unit time increases linearly with temperature from a base temperature $\left(\mathrm{T}_{\text {base }}\right)$ to an optimum temperature of around $30^{\circ} \mathrm{C}$ average. Above this optimum temperature, growth decreases linearly and may even stop when temperature is above $40^{\circ} \mathrm{C}$. To complete a given phenological stage, these cultivars need to accumulate heat (i.e. GDD). Under a warming climate, higher temperatures will result in a more rapid accumulation of GDD and therefore a reduction of some crop development phases and of the global growth cycle.

The analysis of the actual evapotranspiration (ETc) accumulated over the growth cycle of millet and maize cultivars shows a decreasing trend for the period 2011-2030 (Fig. 7, lower panels). This decline is estimated at $7 \%$ at average growth length over all reference stations. However, mid-century, the SP0750 scenario suggests a small increase of 2 to $5 \%$ of ETc over most of the study area. In the scenario of global warming associated with stationary rainfall (SN0), the decrease is estimated at $3 \%$ (over $90 \%$ of
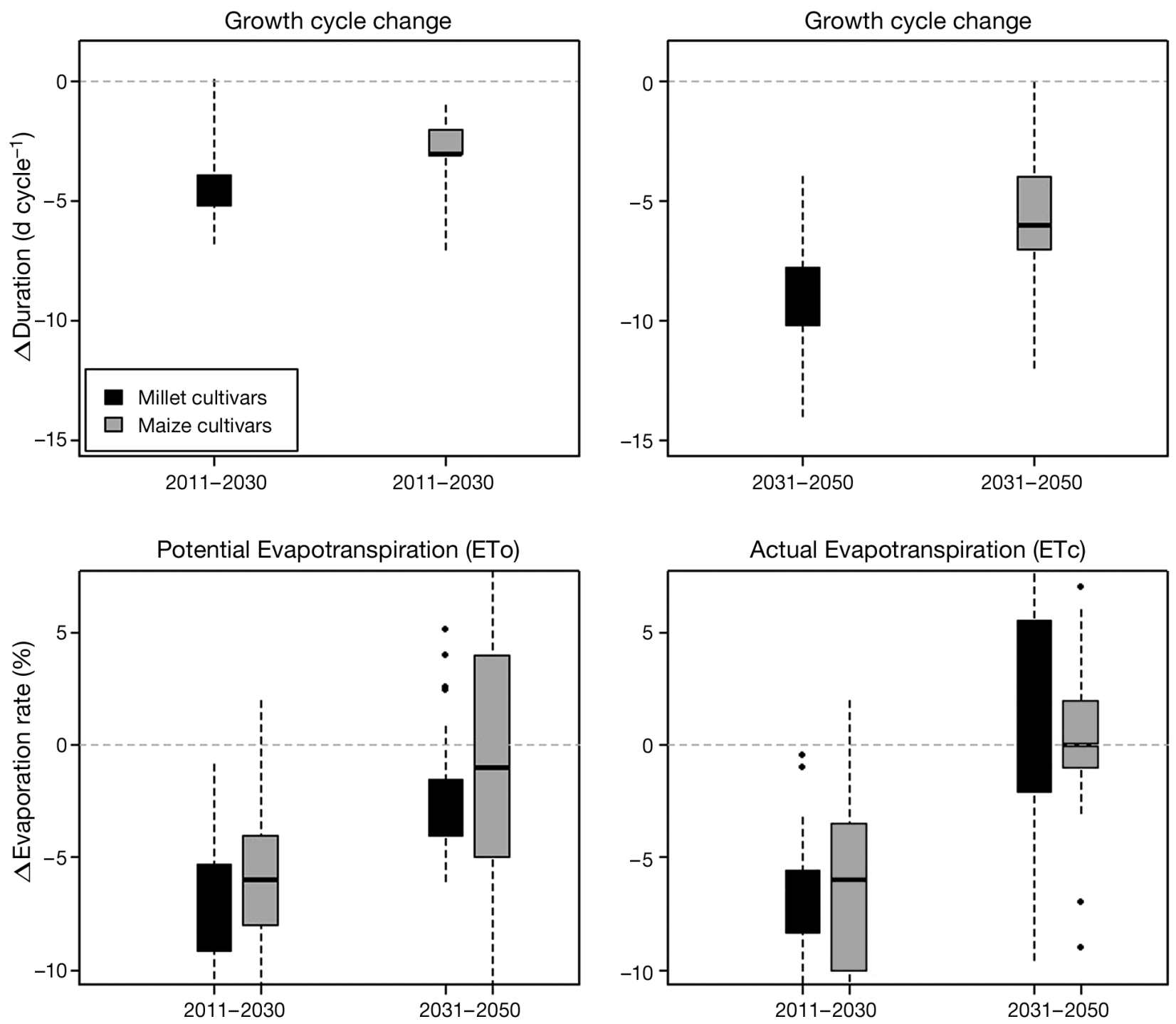

Fig. 7. Effect of warming and rainfall variability on the growth cycle and water requirements of short-cycle cultivars of millet and maize in the West African Sudan-Sahel. Bottom and top of boxes: 25th and 75th percentiles, respectively; horizontal segment inside box: median; whiskers: minimum/maximum; full dots: outliers distributed over the region 
the reference stations) and 5 to $10 \%$ (over more than half of the network) at the beginning and in the middle of the 21st century, respectively. In the first half of the century, the increase in water demand of these short-cycle cultivars is explained by the $10 \%$ decrease in rainfall. However, an increase in rainfall of $7 \%$ cannot totally counterbalance the negative effects of heat stress on water requirements when the warming gets close to $2^{\circ} \mathrm{C}$ in the late 2050s.

\subsubsection{Effects on regional production}

To assess the impact of future climate as suggested by scenario members SN10-30 and SP07-50 (SN0-30 and SN0-50), we calculated the average aboveground biomass and grain yield of each cultivar in the 2020s
(2011-2030) and 2040s (2031-2050). This average was compared to the average of the baseline period 19812010. Fig. 8 shows the relative percent change of aboveground biomass and grain yield over the WASS regional production. Under lower warming conditions of the SN0-30 scenario, the majority of stations in the study area experience a biomass reduction of 2 to $5 \%$ and a grain yield decrease of 5 to $7 \%$. By 2050, results of scenario SN0-50 show a grain yield decrease of 10 to $15 \%$ over the study area (Fig. 8). Small increase rates are observed on biomass production (2 to $4 \%$ ) at some localities. However, the decrease in grain yield exhibits a strong spatial coherence.

In the case of SNP scenarios, there is a general decline in biomass production (grain yield) of 5 to $15 \%$ (8 to $15 \%$ ) in 2011-2030. In the period 20312050 , the decrease reaches 10 to $20 \%$ on grain yield
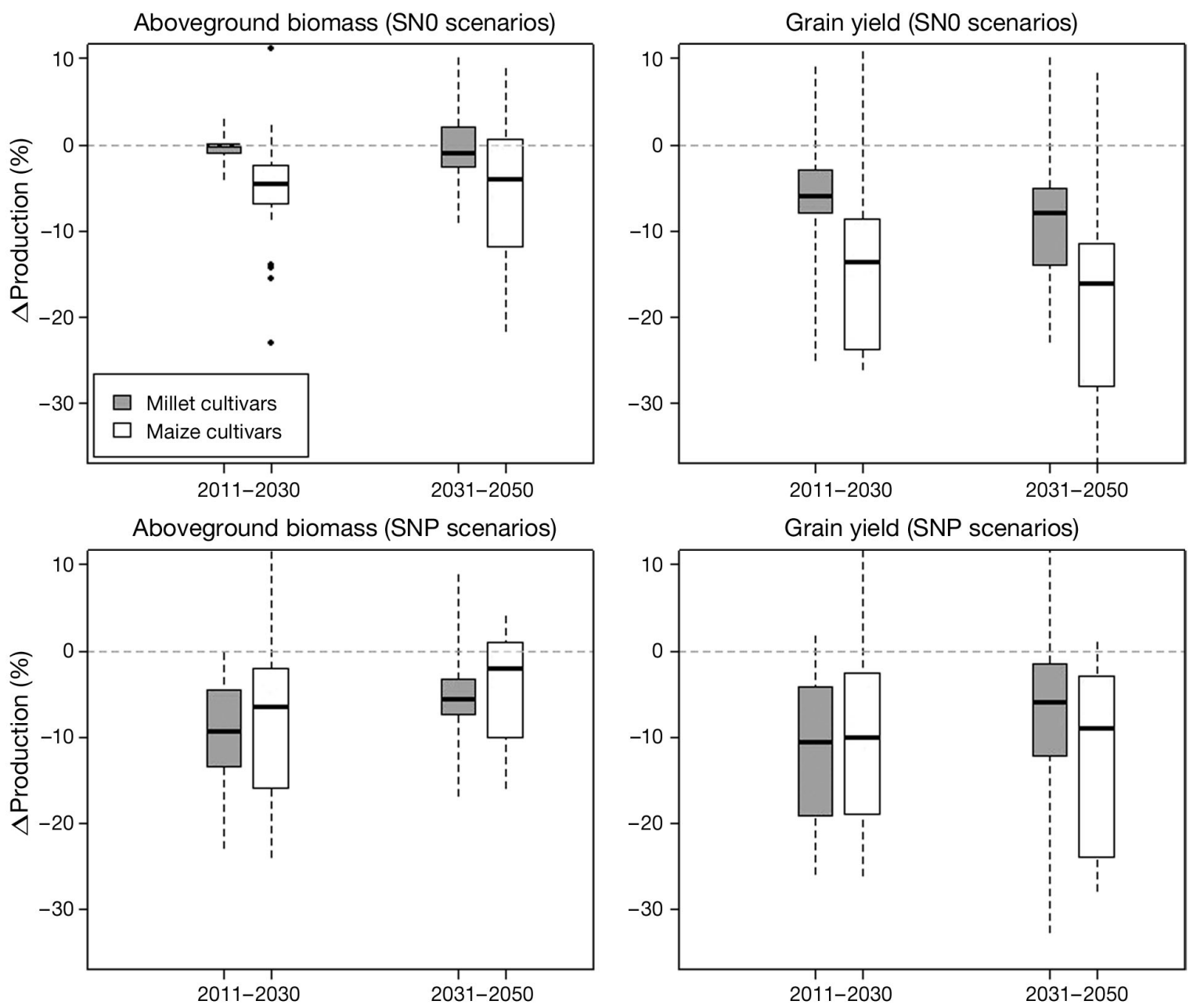

Fig. 8. Percentage change in the production of short-cycle millet cultivars (Souna 3, Zatib and HKP) and maize (OBATAMPA, EV-8443). This percentage is relative to baseline climate from 1981 to 2010. Bottom and top of boxes: 25th and 75th percentiles, respectively; horizontal segment inside box: median; whiskers: minimum/maximum; full dots: outliers distributed over the region 
while the loss in biomass is reduced to 3 to $5 \%$ over the majority of the reference stations (Fig. 8). A decrease in rainfall combined with regional warming causes more loss in grain yield. A slight increase in rainfall associated with an increase in temperature of about $1.8^{\circ} \mathrm{C}$ has a small negative effect on biomass production.

\section{DISCUSSION}

In the WASS region, a wet year does not guarantee good on-farm crop yield. Besides soil erosion, nutrient depletion, insects and parasites, the intraseasonal rainfall distribution is becoming more hazardous, with increasing numbers of extreme events such as longer dry spells, very heavy rainy days, flooding (Alhassane et al. 2013, Salack 2013), warm nights and warm days (Ly et al. 2013). Under atmospheric conditions of gradual warming and a normal rainfall regime (stationary rainfall), the growth cycle of both millet and maize cultivars shortens by 5 to $8 \mathrm{~d}$ and water requirements increase by $7 \%$ on average in the Sudan-Sahel zone of West Africa. The shortening of the growth cycle leads to a spatially coherent loss in grain yield of 5 to $7 \%$ and to a highly variable biomass production in the late 2050s. Heat stress may also affect grain weight and the duration of grain growth, as shown by some experiments in controlled environments (Abrol \& Ingram 1996). However, these small rates of decrease show that millet is less sensitive to warming rates below $2^{\circ} \mathrm{C}$. This behavior can be partly explained by pearl millet's adaptive capacity in adverse conditions, as described by Winkel \& Do (1992).

However, when this moderate climate warming is associated with rainfall variability, the production of millet and maize short-cycle cultivars will be affected in 2 ways: (1) a slight increase in temperature (i.e. +0.6 to $+0.8^{\circ} \mathrm{C}$ ) combined with a moderate decrease in precipitation (i.e. $-10 \%$ ) leads to a 10 to $15 \%$ (8 to $15 \%$ ) decrease in aboveground biomass production (grain yield) and (2) when the warming is moderate (i.e. +1.4 to $1.8^{\circ} \mathrm{C}$ ), the decline in grain yield worsens (10 to $20 \%$ ), despite a slight increase in rainfall in projections $(+7 \%)$.

In a more general approach, by forcing the outputs of climate models directly into the biophysical model agro-DGVM, Berg et al. (2013) showed that C4 plants suffer a negative impact of $6 \%$ (with a range of dispersion of individual scenarios from -29 to $+11 \%$ ). Following the climate classification of Köppen, the contribution of higher temperatures to explain these impacts is moderate and more robust in equatorial and temperate regions. These rates are higher but less robust in arid and semi-arid regions because of uncertainties in the climate model projections in these regions (Berg et al. 2013).

By using ensemble simulations (both crop and climate models) and crop model sensitivity analysis (with respect to crop management practices), our analysis narrows the range of values characterizing the limits within which estimates are expected in a little documented timeline (i.e. 2011-2050). Thus, the results show that in the Sudan-Sahel, a warming below $2^{\circ} \mathrm{C}$ and a decrease in rainfall can magnify loss in grain production of short-cycle cultivars of both millet and maize. However, if the same range of warming is associated with an increase in precipitation, it will only reduce loss of aboveground biomass production. The effect of an increase in temperature greater than $2^{\circ} \mathrm{C}$ has been tested by Sultan et al. (2013). They show that beyond $2^{\circ} \mathrm{C}$, the negative impacts of rising temperature are greater on all production (aboveground biomass and grains). This negative impact cannot be reduced by any increase in rainfall. Therefore, a $1.8^{\circ} \mathrm{C}$ rise over the WASS region would prevent some of the worst impacts reported by recent studies (Sultan et al. 2013, Waha et al. 2013) of the mid- and late 21st century, but still pose a serious challenge to local crop production systems. In other words, if regional warming is kept below $2{ }^{\circ} \mathrm{C}$, adaptation is possible and feasible for rainfed subsistence farming of short-cycle cultivars. However, it requires that climate-smart crop management practices be embedded in sub-seasonal and interannual early warning systems.

\section{SCHEME OF AN EFFECTIVE AGROCLIMATIC EARLY WARNING SYSTEM FOR RESILIENCE}

Our understanding of the consequences of climate variability on rainfed agricultural production in the Sahel has improved in the past 2 decades. However, putting this knowledge into action is not straightforward, as the forecasting skill is still imperfect, and approaches to applying the existing skill to management issues have not been developed and tested extensively (Hammer et al. 2001). While much has been written about the impacts of climate variability, relatively little has been done in relation to applying climate prediction to modify actions ahead of likely impacts in the WASS region. Therefore, the establishment of an agroclimatic monitoring and early warning system (AgMEWS) would be a break- 


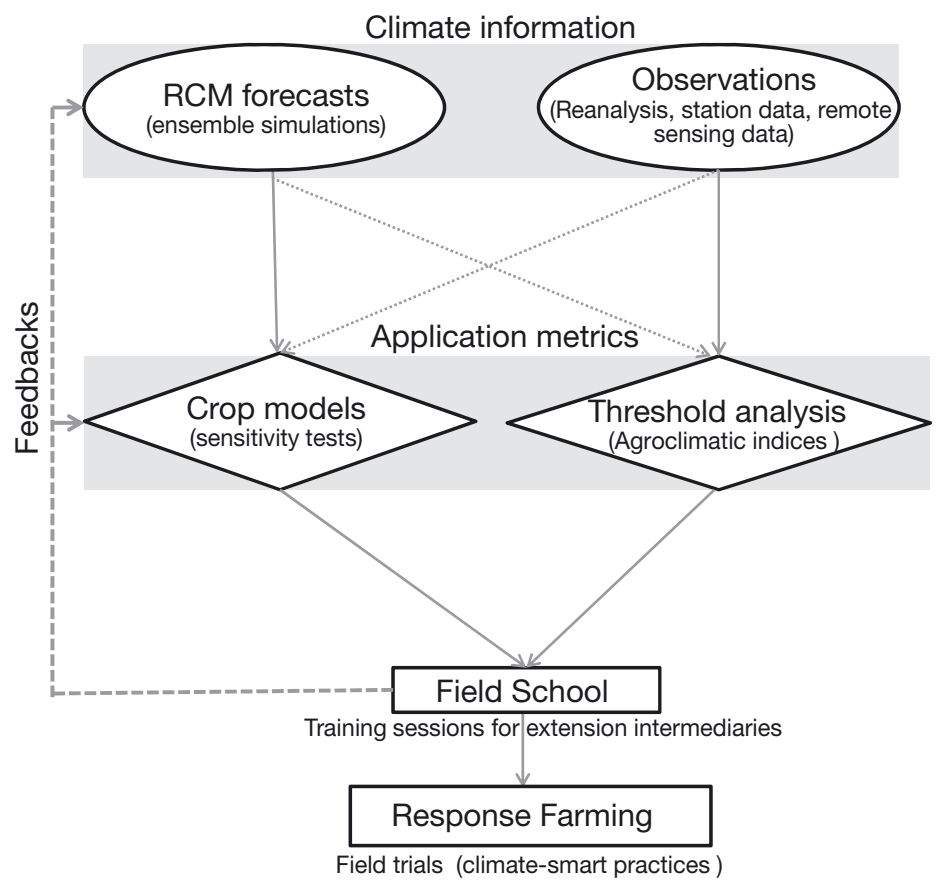

Fig. 9. Scheme of an effective agroclimatic monitoring and early warning system for subsistence farming in West African Sudan-Sahel

through to technical adaptation measures for the region. Fig. 9 illustrates the scheme of an effective AgMEWS for West Africa as developed in the framework of the West African Science Service Center on Climate Change and Adapted Land Use (WASCAL) program. The objective of an AgMEWS is to assist subsistence farmers with climate information to reinforce resilience of the cropping systems to increased climate variability. This is also the concept of response farming defined by FAO: 'Improved information about water supply prospects and about impacts of alternative actions may help reduce the adverse effect of weather and climate variability'.

Based on the multiple research outputs already available, climate-smart practices can be associated with each climatic situation. In other words, every climate scenario can be translated into an adequate farming option. In the specific case of the WASS region, subsistence farming systems need climate information, but farmers also need a practical advisory on how this information can be translated into action and be optimized (Waongo et al. 2014). This can be achieved through farm schools for extension intermediaries such as agronomists, Red Cross volunteers, non-governmental organizations, state rural employees and learned farmers in the region. Lessons learned can be taken from experiences obtained in Indonesia (Stigter \& Winarto 2013). The field schools will establish an avenue for exchange between climate and soil scientists, agronomists, extension intermediaries and farmers. The development of an AgMEWS suggests also that climate-based crop monitoring and forecasting include dynamically embedding crop models within climate models to account for crop influence on regional climate (Hansen et al. 2006) and emerging application metrics such as agroclimatic indices (Laux et al. 2008, Salack et al. 2011, Alhassane et al. 2013). On the one hand, RCM ensemble simulations have made progress (Paeth et al. 2011, Nikulin et al. 2012) and have proven useful for crop forecasting (Oettli et al. 2011, Challinor et al. 2013, Salack 2013). On the other hand, agricultural application metrics such as crop models and agroclimatic indices are continuously tuned to represent the crop-soil-atmosphere continuum at the local scale (Salack et al. 2011, Bationo et al. 2012, Hoogenboom et al. 2012, Alhassane et al. 2013, Waongo et al. 2014).

Most crop models are calibrated based on experimental data and theory. To complete the validation process, they also need to be subjected to on-farm practices and observations. It is therefore incumbent on the user to carry out some sensitivity tests in different agro-ecological zones. Agroclimatic indices are the indicators of farming potentials in a region. They are determined based on the combination of climate, soil characteristics, crop ecophysiology and genetics. They include crop water demand per growth stage; crop water requirements (or irrigation potentials); optimum temperature for germination, vegetation and reproduction; GDDs; lethal temperatures; day length for photoperiodic response; timing and frequency of extreme dry spells and wet spells; and sowing and harvest dates. The threshold analysis of agroclimatic indices consists of identifying the critical detrimental or optimal values to crops/ cropping systems and using them in monitoring and prediction processes (Laux et al. 2008, Waongo et al. 2014). An effective AgMEWS uses both observational data (classical and automatic weather station data, microwave link, satellite-derived or reanalysis data) and RCM ensemble forecasts through the aforementioned application metrics to deliver sub-seasonal and interannual information to local producers and extension intermediaries. Pre-onset information should provide input information on optimum sowing dates (dry/wet seeding or transplantation), seasonal rainfall flags (representation of probabilities of rainfall amount, onset dates, growth periods) and seasonal 
forecast. Agroclimatic information at $30 \mathrm{~d}$ after sowing will include seedling density, weeding calendar and tillage types, fertilizer type, amount and date of incorporation and frequency of rainy days and dry spells. At 90 d after sowing, farmers need climate information on cessation dates, optimum harvest dates and frequency of post-harvest rainy days. Feedback from users about the pros and cons of the provided information ensure a continuous cross-validation process to improve the agroclimatic metrics and the science of monitoring and forecasting over the region.

\section{CONCLUSIONS}

The analysis of recent station data shows the similarity of agroclimatic risks between the historical drought of the 1980s and the last 2 decades. A wide range of variability is found in some influential seasonal parameters such as optimum sowing dates and length of the rainy season. Hazardous rainfall distribution threatens crop productivity with increased frequency and intensity of daily rainfall and false start and early cessation of rainy seasons. These hazards lead to the need for re-planting, to post-flowering water stress, flooding of lowlands, increased water logging potentials and arable land depletion. They partly explain recent food crises in some countries of this region.

Short-cycle cultivars were introduced in the $1970 \mathrm{~s}$ and promoted in the 1980 s as alternative varieties to the shortening of the rainy season and recurrent drought. Today, they are widely used by farmers in traditional rainfed farming systems all over the WASS region. In the context of global warming and rainfall variability, the near-future reductions in production of these cultivars, as we describe here, are likely to increase the potential for food crises. A moderate rate of warming, i.e. $<1^{\circ} \mathrm{C}$, in a stationary rainfall regime may not be as detrimental, with an estimated loss in grain yield of 5 to $7 \%$; but were the warming to reach $2{ }^{\circ} \mathrm{C}$, then the estimated yield loss would increase to 10 to $15 \%$, and water demand would increase 7 to $10 \%$ all over the WASS region. In the case of a decrease in rainfall combined with regional warming, there will be a general decline in biomass production and grain yield by 5 to $15 \%$ and 8 to $15 \%$, respectively, in 2011-2030. In 2031-2050, when the regional warming is expected to be close to $2{ }^{\circ} \mathrm{C}$, the loss reaches 10 to $20 \%$ in grain yields while the loss in biomass is reduced to 3 to $5 \%$ over the majority of the reference stations.

The results update the 'loss and damage' on crop production in a food crisis prone region over the less documented period of 2011-2050. The additional difficulty of countries in this region to maintain sustainable food production is mainly because smallholder farming has limited capacity to adapt to climate variability. Nevertheless, resilience reinforcement is possible and feasible for subsistence cropping systems of short-cycle cultivars in the WASS region. It will, indeed, require that climate-smart crop management practices be embedded in effective sub-seasonal and interannual early warning information and response farming as described above.

Acknowledgements. This work was funded by the European Union through the Global Climate Change Alliance (GCCA) and by the German Federal Ministry of Education and Research (BMBF) through the WASCAL (www.wascal.org). We thank all national meteorological services/agencies for contributing observed data. The authors acknowledge enlightening exchanges and editions from Alessandra Giannini of the International Research Institute for Climate and Society (IRI), Columbia University. Comments and suggestions from 3 anonymous reviewers and the Editor helped to greatly improve the quality of this paper.

\section{LITERATURE CITED}

Djaby B, Koné B, Labo M,Vieri T (2001) Les aptitudes agricoles et pastorales des sols dans les pays du CILSS. IBIMET, Florence

Abrol YP, Ingram KT (1996) Effects of higher day and night temperatures on growth and yields of some crop plants. In: Bazzaz F, Sombroek W (eds) Global climate change and agricultural production. Direct and indirect effects of changing hydrological, pedological and plant physiological processes. Wiley, Chichester, p 124-140

Alexandrov VA, Hoogenboom G (2000) The impact of climate variability and change on crop yield in Bulgaria. Agric For Meteorol 104:315-327

Alhassane A, Traoré SB, Zouzou M, Sarr B, Amadou M (2006) Effet de la fertilisation azotée de couverture et de la densité de semis sur la consommation hydrique d'une variété de mil au Niger. Sciences Naturelles et Agronomie 28:99-116

Alhassane A, Salack S, Ly M, Lona I, Traoré SB, Sarr B (2013) Evolution des risques agroclimatiques associés aux tendances récentes du régime pluviométrique en Afrique de l'Ouest Soudano-Sahelienne. Sécheresse 24: 282-293

Annou GM (2003) Les grands types de sols du Niger. In: Quatorzième réunion du Sous-Comité ouest et centre africain de corrélation des sols. Food and Agriculture Organization of the United Nations (FAO), Rome, p 151-167

Balme M, Galle S, Lebel T (2005) Démarrage de la saison des pluies au Sahel: variabilité aux échelles hydrologique et agronomique, analysée à partir des données EPSAT-Niger. Sécheresse 16:15-22

Baron C, Sultan B, Balme M, Sarr B and others (2005) From GCM grid cell to agricultural plot: scale issues affecting modeling of climate impact. Philos Trans R Soc Lond B 360:2095-2108 
Bationo A, Tabo R, Kihara J, Hoogenboom G, Traore PCS, Boote KJ, Jones JW (2012) Building capacity for modelling in Africa. In: Kihara J, Fatondji D, Jones JW, Hoogenboom G, Tabo R, Bationo A (eds) Improving soil fertility recommendations in Africa using the Decision Support System for Agrotechnology Transfer (DSSAT). Springer, Dordrecht, p 1-7

> Berg A, de Noblet-Ducoudré N, Sultan B, Lengaigne M, Guimberteau M (2013) Projections of climate change impacts on potential C4 crop productivity over tropical regions. Agric For Meteorol 170:89-102

Challinor AJ, Smith MS, Thornton P (2013) Use of agroclimate ensembles for quantifying uncertainty and informing adaptation. Agric For Meteorol 170:2-7

Cook K (2008) Climate science: the mysteries of Sahel droughts. Nat Geosci 1:647-648

FAO/UNESCO (Food and Agriculture Organization of the United Nations/United Nations Educational, Scientific and Cultural Organization) (2003) Digitized soil map of the world and derived soil properties (version 3.5). FAO Land and Water Digital Media Series No. 1. FAO, Rome

> Giannini A, Saravanan R, Chang P (2003) Oceanic forcing of Sahel rainfall on interannual to interdecadal time scales. Science 302:1027-1030

Giannini A, Salack S, Lodoun T, Ali A, Gaye AT, Ndiaye O (2013) A unifying view of climate change in the Sahel linking intra-seasonal, interannual and longer time scales. Environ Res Lett 8:024010

Gijsman AJ, Thornton PK, Hoogenboom G (2007) Using the WISE database to parameterize soil inputs for crop simulation models. Comput Electron Agric 56:85-100

Hammer GL, Hansen JW, Phillips JG, Mjelde JW, Hill H, Love A, Potgieter A (2001) Advances in application of climate prediction in Agriculture. Agric Syst 70:515-553

Hansen JW, Challinor A, Ines A, Wheeler T, Moron V (2006) Translating climate forecasts into agricultural terms: advances and challenges. Clim Res 33:27-41

Hoogenboom G, Jones JW, Wilkens PW, Porter CH and others (2010) Decision Support System for Agrotechnology Transfer (DSSAT) Version 4.5. University of Hawaii, Honolulu

Hoogenboom G, Jones JW, Traore PCS, Boote KJ (2012) Experiments and data for model evaluation and application. In: Kihara J, Fatondji D, Jones JW, Hoogenboom G, Tabo R, Bationo A (eds) Improving soil fertility recommendations in Africa using the Decision Support System for Agrotechnology Transfer (DSSAT). Springer, Dordrecht, p 9-18

IPCC (2007) Climate change 2007: impacts, adaptation and vulnerability. In: Parry ML, Canziani OF, Palutikof JP, van der Linden PJ, Hanson CE (eds) Contribution of Working Group II to the Fourth Assessment Report of the Intergovernmental Panel on Climate Change. Cambridge University Press, Cambridge

Jones HG (1992) Plants and microclimate: a quantitative approach to environmental plant physiology, 2nd edn. Cambridge University Press, Cambridge

Jones JW, Hoogenboom G, Porter CH, Boote KJ and others (2003) The DSSAT cropping system model. Eur J Agron 18:235-265

Keita B (2003) Les sols dominants du Mali. In: Quatorzième réunion du Sous-Comité ouest et centre africain de corrélation des sols. Food and Agriculture Organization of the United Nations (FAO), Rome, p 95-103

Khouma M (2003) Les grands types de sols du Sénégal. In:
Quatorzième réunion du Sous-Comité ouest et centre africain de corrélation des sols. Food and Agriculture Organization of the United Nations (FAO), Rome, p 77-94

Kissou R, Thiombiano L, Nébié AK, Semde A, Yago KJ (2003) La base mondiale de données sur les sols: avantages et faiblesses pour la connaissance et l'utilisation des milieux édaphiques au Burkina Faso. In: Quatorzième réunion du Sous-Comité ouest et centre africain de corrélation des sols. Food and Agriculture Organization of the United Nations (FAO), Rome, p 121-149

> Laux P, Kunstmann H, Bardossy A (2008) Predicting the regional onset of the rainy season in West Africa. Int $\mathrm{J}$ Climatol 28:329-342

Le Barbé L, Lebel T, Tapsoba D (2002) Rainfall variability in West Africa during the years 1950-90. J Clim 15:187-202

Lebel T, Ali A (2009) Recent trends in the central and western Sahel rainfall regime (1990-2007). J Hydrol (Amst) doi:10.1016/j.jhydrol.2008.11.030

> Lobell DB (2013) Errors in climate datasets and their effects on statistical crop models. Agric For Meteorol 170:58-66

> Ly M, Traore SB, Agali A, Sarr B (2013) Evolution of some observed climate extremes in the West African Sahel. Weather Clim Extremes 1:19-25

Neelin JD, Chou C, Su H (2003) Tropical drought regions in global warming and El Nino teleconnections. Geophys Res Lett 30:2275

> Nikulin G, Jones C, Giorgi F, Asrar G and others (2012) Precipitation climatology in an ensemble of CORDEX-Africa regional climate simulations. J Clim 25:6057-6078

> Oettli P, Sultan B, Baron C, Vrac M (2011) Are regional climate models relevant for crop yield prediction in West Africa? Environ Res Lett 6:014008

Paeth H, Hall NM, Gaertner MA, Alonso MD and others (2011) Progress in regional downscaling of West African precipitation. Atmos Sci Lett 12:75-82

Porter JR, Xie L, Challinor AJ, Cochrane K and others (2014) Food security and food production systems. In: Field CB, Barros VR, Dokken DJ, Mach KJ and others (eds) Climate change 2014: impacts, adaptation, and vulnerability. Part A. Global and sectoral aspects. Contribution of Working Group II to the Fifth Assessment Report of the Intergovernmental Panel on Climate Change. Cambridge University Press, Cambridge, p 485-533

Salack S (2013) Analyse des pauses pluviométriques et évaluation des incertitudes de la pluie des modèles régionaux de climat à l'aide d'un modèle de culture (Analysis of dry spells and evaluation of uncertainties in RCMs' precipitation, using a crop model). PhD dissertation, University Cheikh Anta Diop, Dakar

Salack S, Sultan B, Oettli P, Muller B, Gaye AT, Hourdin F (2012) Représentation de la pluie dans les modèles régionaux de climat et application a l'estimation des rendements du mil au Sénégal. Sécheresse 23:14-23

Salack S, Muller B, Gaye AT (2011) Rain-based factors of high agricultural impacts over Senegal. I. Integration of local to sub-regional trends and variability. Theor Appl Climatol 106:1-22

Salack S, Giannini A, Diakhaté M, Gaye AT, Muller B (2014) Oceanic influence on the subseasonal to interannual timing and frequency of extreme dry spells over the West African Sahel. Clim Dyn 42:189-201

Sarr B (2011) Present and future climate change in West Africa: a crucial input for agricultural research prioritization for the region. Atmos Sci Lett 13:108-112 
Stigter CJ, Winarto YT (2013) Science field shops in Indonesia. A start of improved agricultural extension that fits a rural response to climate change. J Agric Sci Appl 2: $112-123$

Sultan B, Janicot S, Baron C, Dingkuhn M, Muller B, Traoré S, Sarr B (2008) Les impacts agronomiques du climat en Afrique de l'Ouest: une illustration des problèmes majeurs. Sécheresse 19:29-37

Sultan B, Roudier P, Quiron P, Alhassane A and others (2013) Assessing climate change impacts on sorghum and millet yields in the Sudanian and Sahelian savannas of West Africa. Environ Res Lett 8:014040

Waha K, Müller C, Rolinski S (2013) Separate and combined

Submitted: June 16, 2014; Accepted: November 26, 2014 effects of temperature and precipitation change on maize yields in sub-Saharan Africa for mid- to late-21st century. Global Planet Change 106:1-12

> Waongo M, Laux P, Traore SB, Sanon M, Kunstmann H (2014) A crop model and fuzzy rule based approach for optimizing maize planting dates in Burkina Faso, West Africa. J Appl Meteorol Climatol 53:598-623

- White JW, Hoogenboom G, Kimball BA, Wall GW (2011) Methodologies for simulating impacts of climate change on crop production. Field Crops Res 124:357-368

Winkel T, Do F (1992) Caractéristiques morphologiques et physiologiques de résistance du mil (Pennisetum glaucum (L.) R. Br.) à la sécheresse. Agron Trop 46:339-351

Proofs received from author(s): June 14, 2015 